\title{
BINOL Macrocycle Derivatives: Synthesis of New Dinaphthyl Sulfide Aza Oxa Thia Crowns (Lariats)
}

\author{
Abbas Shockravi, ${ }^{1,2}$ Shahram Mehdipour-Ataei, ${ }^{3}$ and Esmael Rostami ${ }^{4}$ \\ ${ }^{1}$ Faculty of Chemistry, Tarbiat Moallem University, Mofatteh Avenue, No. 49, Tehran 15614, Iran \\ ${ }^{2}$ Faculty of Chemistry, Tarbiat Moallem University, 31979-37551, Karaj, Iran \\ ${ }^{3}$ Polyurethanes \& Advanced Polymeric Materials Department, Faculty of Polymer Science, Iran Polymer \& Petrochemical Institute \\ (IPPI), P.O. Box 14965/115, Tehran, Iran \\ ${ }^{4}$ Department of Chemistry, Payame Noor University, P.O. Box 19395-3697, Tehran 19569, Iran
}

Correspondence should be addressed to Esmael Rostami; esmaelrostami@gmail.com

Received 6 August 2011; Revised 20 June 2012; Accepted 16 July 2012

Academic Editor: Dario Pasini

Copyright (C) 2013 Abbas Shockravi et al. This is an open access article distributed under the Creative Commons Attribution License, which permits unrestricted use, distribution, and reproduction in any medium, provided the original work is properly cited.

In this research work, dinaphthyl sulfide diester was prepared from the reaction of $1,1^{\prime}$-thiobis (2-hydroxy naphthalene) and methylchloroacetate. Its aza-macrocyclic derivative was synthesized from the reaction of dinaphthyl sulfide diester and diethylenetriamine. Lariats were prepared from the reaction of chloroamides (four derivatives) and initial macrocycle. Chloroamides were synthesized from the reaction of amines (aniline, benzylamine, 8-amino quinoline and 4-amino azobenzene) and chloroacetyl chloride. All the materials were identified by IR, ${ }^{1} \mathrm{H}$ NMR, ${ }^{13} \mathrm{C}$ NMR, and mass spectroscopies, and elemental analysis.

\section{Introduction}

Since the initial publications on the synthesis of crown ethers and their metal salt complexation properties $[1,2]$, the influence of structural variation within such ligands has received increasing attention [3-12]. One such structural variation is the replacement of one ether oxygen with nitrogen to give an azacrown ether $[13,14]$ or sulfur group to obtain thiacrown ether $[14,15]$. Another is the attachment of a functional side arm to the ligand framework to provide the potential for three-dimensional complexation of metal ions. Such armed crown ethers have been designated as lariat ethers [16-18]. If the side arm attachment site is a carbon atom of the macrocycle, the ligand is called a C-pivot lariat ether. If it is a nitrogen atom of azacrown ether, the ligand is identified as a $\mathrm{N}$-pivot lariat ether.

Efficient syntheses of $\mathrm{N}$-pivot lariat ethers in which phenolic and hydroxyquinoline units are attached to an aza crown ether nitrogen by a methylene group have been developed using the Mannich reaction [19]. A lot of lariat aza-macrocycles were synthesized in which their side chain containing several functional groups such as ether [20], amide [21, 22], acid [23], nitrogen [24], and other functional groups that have an active rule in binding properties towards various kinds of guests.

BINOL is an important building block in chemistry. A large number of BINOL derivatives have been explored, and important BINOL derivatives are BINOL crown ethers and macrocycles. The study of optically active BINOL compounds and the new derivatives of these compounds is an active route in organic synthesis in recent years [25-32]. According to the Figure 1, BINOL and dinaphthyl sulfides are derivatives. In the dinaphthyl sulfides structure, sulfur atom is a strong donor atom for complexation properties and as a result dinaphthyl sulfide has stronger donor atoms in comparison with BINOL. Several works were performed for the application of dinaphthyl sulfide derivatives (podands and aza crowns): the study of complex formation with silver atoms [33], complexation with $\mathrm{Pb}^{2+}, \mathrm{Ni}^{2+}$, and $\mathrm{Hg}^{2+}$ [34], $\mathrm{Hg}^{2+}$ [35], $\mathrm{Pb}^{2+}$ [36], $\mathrm{Ag}^{+}$[37], $\mathrm{Cu}^{2+}$ [38]. Dinaphthyl sulfide aza crowns diffuse across the cell membranes and interfere with 
<smiles>Oc1ccc2ccccc2c1-c1c(O)ccc2ccccc12</smiles>

BINOL<smiles>[R]Oc1ccc2ccccc2c1Sc1c(O[R])ccc2ccccc12</smiles>

Dinaphthosulfides
FIgURE 1: The structure of BINOL and dinaphthyl sulfides.

different living systems [39]. All of these research works show that the dinaphthyl sulfide receptors have a large number of applications in chemistry and related areas.

In this research work, new dinaphthyl sulfide lariats were prepared. These compounds are the aza oxa thia crowns bearing naphthol building blocks. The study of these compounds and their derivatives is underway.

\section{Experimental}

The reactions were carried out in an efficient hood. All the materials were purchased from Merck, Fluka, and Aldrich chemical companies. Methanol and dichloromethane were distilled and stored under Lind $4 \AA$ molecular sieves. Compound 1 was synthesized based on the reported procedure [33-38]. Two chloroamides (6 and 7) were reported previously [40-42]. The melting points (uncorrected) were measured with an Electrothermal Engineering Ltd. 9100 apparatus. Elemental analysis was performed by a CHN-ORapid Heraeus elemental analyzer. IR spectra were measured on a Perkin-Elmer model 543, the ${ }^{1} \mathrm{H}$ NMR and ${ }^{13} \mathrm{C}$ NMR spectra were obtained using Bruker Avance DPX $300 \mathrm{MHz}$ and Bruker Avance DRX $500 \mathrm{MHz}$ apparatus, and mass spectra were obtained with Shimadzu GC-MS-QP 1100 EX model.

2.1. General Procedure (1), the Synthesis of $\alpha$-Chloroamide Derivatives (4-7). To a vigorously stirred solution of amine $(2 \mathrm{mmol})$ and triethylamine $(2 \mathrm{mmol})$ in an appropriate dried solvent $\left(50 \mathrm{~mL}, \mathrm{CH}_{2} \mathrm{Cl}_{2}\right.$ or $\left.\mathrm{CH}_{3} \mathrm{CN}\right)$ a solution of chloroacetyl chloride $(2 \mathrm{mmol})$ was added in the same solvent $(50 \mathrm{~mL})$ at $0^{\circ} \mathrm{C}$. The reaction mixture was stirred at room temperature for $6 \mathrm{~h}$. After completion of the reaction (monitored by TLC), the reaction mixture was quenched with distilled water $(50 \mathrm{~mL})$ and then was extracted with $\mathrm{CH}_{2} \mathrm{Cl}_{2}$ $(2 \times 50 \mathrm{~mL})$. The combined organic layers were washed with $10 \%$ aqueous $\mathrm{HCl}$ solution $(50 \mathrm{~mL})$ and water $(50 \mathrm{~mL})$, dried $\left(\mathrm{Na}_{2} \mathrm{SO}_{4}\right)$, and evaporated to afford solid products which were purified by recrystallization from ethanol.

2.1.1. Synthesis of 3-Aza-2-oxo-3-phenyl-propylchloride (4). This chloroamide (4) was prepared from the reaction of aniline and chloroacetyl chloride based on the general procedure (1) and afforded as a white powder in $94 \%$ yield, mp $94-95^{\circ} \mathrm{C}$; IR (KBr): 3266, 3069, 2978, 1657, 1601, 1547, 1483, 1444,
$1418,1365,1343,1231,1199,1104,927,785 \mathrm{~cm}^{-1} ;{ }^{1} \mathrm{H}$ NMR $\left(300 \mathrm{MHz}, \mathrm{CDCl}_{3}\right) \delta: 4.18(\mathrm{~s}, 2 \mathrm{H}), 7.18(\mathrm{tt}, J=9,1.2 \mathrm{~Hz}$, $1 \mathrm{H}), 7.37(\mathrm{tdd}, J=9,3,1.8 \mathrm{~Hz}, 2 \mathrm{H}), 7.56(\mathrm{dt}, J=6,3 \mathrm{~Hz}$, 2H), 8.24 (b, 1H) ppm; ${ }^{13} \mathrm{C} \mathrm{NMR}\left(75 \mathrm{MHz}, \mathrm{CDCl}_{3}\right): \delta 49.36$, $126.25,127.82,128.75,142.34,164.79$ ppm; Anal. Calcd. for $\mathrm{C}_{8} \mathrm{H}_{8}$ CINO: C, 56.65; H, 4.75; N, 8.26. Found: C, 56.63; H, $4.76 ; \mathrm{N}, 8.28$.

2.1.2. Synthesis of 3-Aza-2-oxo-4-phenyl-butyl chloride (5). This chloroamide (5) was prepared from the reaction of benzyl amine and chloroacetyl chloride based on the general procedure (1) and obtained as white needles in $96 \%$ yield, $\mathrm{mp}$ 89-90 ${ }^{\circ} \mathrm{C}$; IR (KBr): 3264, 3059, 2978, 1658, 1601, 1546, 1489, $1443,1418,1368,1342,1231,1198,1104,927,784 \mathrm{~cm}^{-1}$; ${ }^{1} \mathrm{H}$ NMR $\left(300 \mathrm{MHz}, \mathrm{CDCl}_{3}\right) \delta: 4.11(\mathrm{~s}, 2 \mathrm{H}), 4.50$ (d, $J=$ $6 \mathrm{~Hz}, 2 \mathrm{H}), 6.87(\mathrm{~b}, 1 \mathrm{H}), 7.26-7.39(\mathrm{~m}, 5 \mathrm{H}) \mathrm{ppm} ;{ }^{13} \mathrm{C} \mathrm{NMR}$ $\left(75 \mathrm{MHz} \mathrm{CDCl}_{3}\right): \delta 42.63,49.32,126.15,127.62,128.79$, 142.38, 164.99 ppm; Anal. Calcd. for $\mathrm{C}_{9} \mathrm{H}_{10} \mathrm{ClNO}$ :, 58.86 ; H, 5.49; N, 7.63. Found C, 58.84; H, 5.50; N, 7.65.

2.2. General Procedure (2), the Synthesis of Lariats (8-11). To macrocycle (3) (1 mmol, $0.50 \mathrm{~g})$ in acetonitrile $(50 \mathrm{~mL})$ alkylating agents were added (one of the chloroamides (4-7) for each reaction) ( $1 \mathrm{mmol})$, sodium carbonate ( $1 \mathrm{mmol}, 0.14 \mathrm{~g})$, sodium iodide (catalytic), and dimethylformamide (DMF, $5 \mathrm{~mL}$ ). The resulting mixture was stirred at room temperature for $24 \mathrm{~h}$. After completion of the reaction (monitored by TLC), water $(50 \mathrm{~mL})$ was added, the mixture was extracted with chloroform $(3 \times 50 \mathrm{~mL})$, and washed with $\mathrm{HCl}(10 \%$, $2 \times 50 \mathrm{~mL}$ ), respectively; the combined chloroform layers were dried $\left(\mathrm{Na}_{2} \mathrm{SO}_{4}\right)$ and evaporated to afford crude product which was purified by column chromatography on silica gel.

2.2.1. Synthesis of 7,10,13-Triaza-1-thia-16,4-dioxa-10-(3-aza -2-oxo-3-(8-quinolyl) propyl)-6,14-dioxo-2,3;17,18-dinaphthyl-cyclooctadecane (8). This azacrown (8) was synthesized from the reaction of quinoline chloroamide (6) and macrocycle (3) based on the general procedure (2) and purified by column chromatography on silica gel using $\mathrm{CH}_{2} \mathrm{Cl}_{2} /$ Methanol (3:1) as eluent, the yield was $76 \%$ and $\mathrm{mp} 230-231^{\circ} \mathrm{C}$; IR (KBr): 3407, 3348, 3069, 2945, 2843, 1686, 1670, 1596, 1553, $1534,1510,1491,1430,1329,1280,1092,1031,813 \mathrm{~cm}^{-1}$; ${ }^{1} \mathrm{H}$ NMR $\left(300 \mathrm{MHz}, \mathrm{DMSO}-\mathrm{d}_{6}\right) \delta: 2.72(\mathrm{~s}, 4 \mathrm{H}), 3.33(\mathrm{~s}$, $4 \mathrm{H}), 3.46(\mathrm{~s}, 2 \mathrm{H}), 4.47$ (s, 4H), 7.23-7.30 (m, 3H), 7.35-7.45 $(\mathrm{m}, 5 \mathrm{H}), 7.53(\mathrm{~d}, J=6 \mathrm{~Hz}, 1 \mathrm{H}),, 7.77(\mathrm{~b}, 2 \mathrm{H}), 7.90(\mathrm{~d}$, $J=9 \mathrm{~Hz}, 4 \mathrm{H}), 8.23(\mathrm{~d}, 1 \mathrm{H}, J=6 \mathrm{~Hz}), 8.25(\mathrm{~d}, J=$ $3 \mathrm{~Hz}, 1 \mathrm{H}), 8.37(\mathrm{~d}, J=9 \mathrm{~Hz}, 2 \mathrm{H}), 8.81(\mathrm{~d}, J=3 \mathrm{~Hz}$, 1H), $10.21(\mathrm{~s}, 1 \mathrm{H}) \mathrm{ppm} ;{ }^{13} \mathrm{C}$ NMR $\left(75 \mathrm{MHz}, \mathrm{DMSO}-\mathrm{d}_{6}\right) \delta$ : $169.85,167.55,155.94,148.88,137.91,136.45,134.12,133.89$, $130.18,129.47,128.70,127.67,127.34,126.70,124.15,124.09$, $121.88,121.74,117.16,116.38,114.84,68.00,58.47,53.61$, $36.55 \mathrm{ppm} ; \mathrm{MS}(\mathrm{EI}) \mathrm{m} / \mathrm{z}: 685[\mathrm{M}]^{+}(4 \%), 648(6 \%), 514$ (13\%), 300 (5\%), 216 (25\%), 187 (28\%), 144 (100\%), 115 (63\%), 91 (8\%), 63 (8\%); Anal. Calcd. for $\mathrm{C}_{39} \mathrm{H}_{35} \mathrm{~N}_{5} \mathrm{O}_{5} \mathrm{~S}$ : C, 68.30; H, 5.14; N, 10.21. Found C, 68.27; H, 5.15; N, 10.23 . 

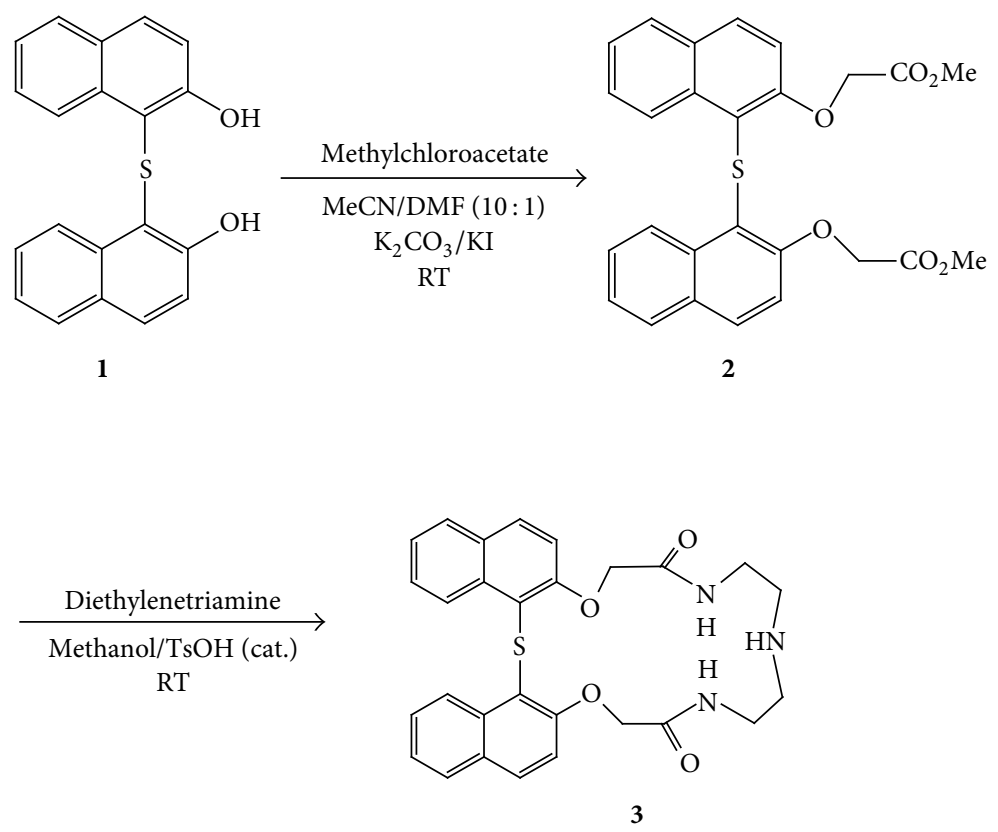

Scheme 1: Synthesis of initial macrocycle (3).

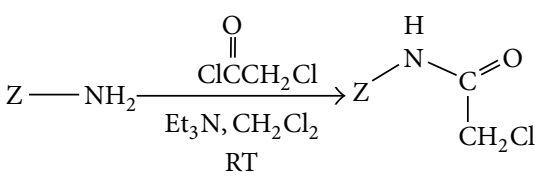

Z (chloroamide): Ph (4), Bn (5), 8-quinolyl (6), 4-azobenzene (7)

SCHEME 2: Synthesis of $\alpha$-chloroamide derivatives.

2.2.2. Synthesis of 7,10,13-Triaza-1-thia-16, 4-dioxa-10-(3aza-2-oxo-3-(phenylazo benzene) propyl)-6, 14-dioxo-2, 3; 17, 18-dinaphtho-cyclooctadecane (9). This aza crown (9) was synthesized from the reaction of azobenzene chloroamide (7) and macrocycle (3) based on the general procedure (2) and purified by column chromatography on silica gel using $\mathrm{CH}_{2} \mathrm{Cl}_{2} /$ Methanol $(4: 1)$ as eluent, the yield was $85 \%$ and mp 251-252 ${ }^{\circ} \mathrm{C}$; IR (KBr): 3406, 3074, 2951, 1686, 1671, 1601, $1546,1511,1468,1447,1435,1417,1256,1230,1159,1079$, $1032,784,693,564 \mathrm{~cm}^{-1} ;{ }^{1} \mathrm{H}$ NMR $\left(300 \mathrm{MHz}, \mathrm{DMSO}-\mathrm{d}_{6}\right)$ $\delta: 2.64(\mathrm{~s}, 2 \mathrm{H}), 3.31-3.33(\mathrm{~m}, 6 \mathrm{H}), 4.41(\mathrm{~s}, 4 \mathrm{H}), 4.59(\mathrm{~s}$, $2 \mathrm{H}), 6.81-7.59$ (m, 12H), $7.90(\mathrm{~s}, 9 \mathrm{H}), 8.36(\mathrm{~d}, 1 \mathrm{H}), 8.44(\mathrm{~d}$, $2 \mathrm{H}) \mathrm{ppm} ;{ }^{13} \mathrm{C}$ NMR $\left(75 \mathrm{MHz}, \mathrm{DMSO}-\mathrm{d}_{6}\right) \delta: 167.58,156.10$, $151.99,134.18,133.99,131.03,130.13,129.52$, 129.40, 128.65, $127.36,124.07,123.66,123.52,122.32,119.87,119.76,119.10$, $118.84,116.74,115.00,114.68,68.11,67.71,45.78,36.68$ ppm; MS (EI) m/z: $738[\mathrm{M}]^{+}(7 \%), 475(9 \%), 474(12 \%), 434(18 \%)$, 385 (22\%), 377 (15\%), 370 (13\%), 369 (15\%), 300 (13\%), 289 (19\%), 264 (15\%), 226 (5\%), 224 (6\%), 197 (74\%), $184(22 \%)$, 144 (10\%), 120 (41\%), 92 (77\%), 91 (100\%), 90 (52\%), 77 (85\%), 66 (33\%), 65 (69\%), 52 (53\%), 39 (42\%); Anal. Calcd. for $\mathrm{C}_{42} \mathrm{H}_{38} \mathrm{~N}_{6} \mathrm{O}_{5} \mathrm{~S}$ : C, 68.27; $\mathrm{H}, 5.18 ; \mathrm{N}, 11.37$. Found C, 68.26; $\mathrm{H}, 5.19 ; \mathrm{N}, 11.40$.
2.2.3. Synthesis of 7,10,13-Triaza-1-thia-16,4-dioxa-10-(3aza-2-oxo-4-phenyl butyl) propyl)-6,14-dioxo-2,3;17,18dinaphthyl-cyclooctadecane (10). This aza crown (10) was synthesized from the reaction of macrocycle(3) and benzyl amine chloroamide (5) based on the general procedure (2) and purified by column chromatography on silica gel using $\mathrm{CH}_{2} \mathrm{Cl}_{2} / \mathrm{Methanol}(4: 1)$ as eluent, the yield was $83 \%$ and mp 228-229 ${ }^{\circ}$; IR (KBr): 3392, 3070, 2946, 2872, 1683, 1628, $1595,1538,1509,1466,1433,1357,1328,1274,1229,1155$, $1084,1031,815,760 \mathrm{~cm}^{-1} ;{ }^{1} \mathrm{H}$ NMR $\left(300 \mathrm{MHz}, \mathrm{DMSO}-\mathrm{d}_{6}\right)$ $\delta: 2.58(\mathrm{~s}, 4 \mathrm{H}), 3.03(\mathrm{~s}, 2 \mathrm{H}), 3.18(\mathrm{~s}, 4 \mathrm{H}), 3.95(\mathrm{~s}, 2 \mathrm{H}), 4.41$ $(\mathrm{s}, 4 \mathrm{H}), 7.02(\mathrm{~s}, 1 \mathrm{H}), 7.20-7.44(\mathrm{~m}, 11 \mathrm{H}), 7.58(\mathrm{~s}, 1 \mathrm{H}), 7.85$ (dd, $J=9.2,15.2 \mathrm{~Hz}, 4 \mathrm{H}), 8.05(\mathrm{~s}, 1 \mathrm{H}), 8.38(\mathrm{~d}, J=8.4 \mathrm{~Hz}$, $2 \mathrm{H}) \mathrm{ppm} ;{ }^{13} \mathrm{C}$ NMR $\left(75 \mathrm{MHz}, \mathrm{DMSO}-\mathrm{d}_{6}\right) \delta: 170.05,167.41$, $155.97,139.17,134.12,130.21,129.43,128.65,128.31,128.15$, $127.34,127.18,127.12,126.88,126.67,124.15,124.06,117.16$, $114.67,67.93,56.14,52.93,42.44,41.63,36.20,30.94 \mathrm{ppm}$; MS (EI) m/z: $649[\mathrm{M}+1]^{+}(5 \%), 648[\mathrm{M}]^{+}(7 \%), 516(8 \%)$, $515(17 \%), 514(100 \%), 501(5 \%), 318(1 \%), 300(26 \%)$, $216(30 \%), 187(49 \%), 144(77 \%), 115(75 \%), 91(100 \%)$, 85 (48\%), 77 (12\%), 65 (18\%), 42 (49\%); Anal. Calcd. for $\mathrm{C}_{37} \mathrm{H}_{36} \mathrm{~N}_{4} \mathrm{O}_{5} \mathrm{~S}: \mathrm{C}, 68.50 ; \mathrm{H}, 5.59 ; \mathrm{N}, 8.64$. Found $\mathrm{C}, 68.53 ; \mathrm{H}$, $5.58 ; \mathrm{N}, 8.66$.

2.2.4. Synthesis of 7,10,13-Triaza-1-thia-16,4-dioxa-10-(3aza-2-oxo-3-phenyl propyl)-6,14-dioxo-2,3;17,18-dinaphthocyclooctadecane (11). This aza crown (11) was synthesized from the reaction of macrocycle (3) and aniline chloroamide (4) based on the general procedure (2) and purified by column chromatography on silica gel using $\mathrm{CHCl}_{3} / \mathrm{Methanol}$ (4:1) as eluent, the yield was $89 \%$ and $\mathrm{mp} 222-223^{\circ} \mathrm{C}$; IR (KBr): 3385, 3054, 2936, 1688, 1679, 1623, 1601, 1558, 1540, 1503, 1446, 1323, 1263, 1225, 1152, 1079, $765 \mathrm{~cm}^{-1} ;{ }^{1} \mathrm{H}$ NMR (300 MHz, DMSO-d 6 ) $\delta: 3.49$ (b, 4H), 3.62 (s, 4H), 4.27 (b, 

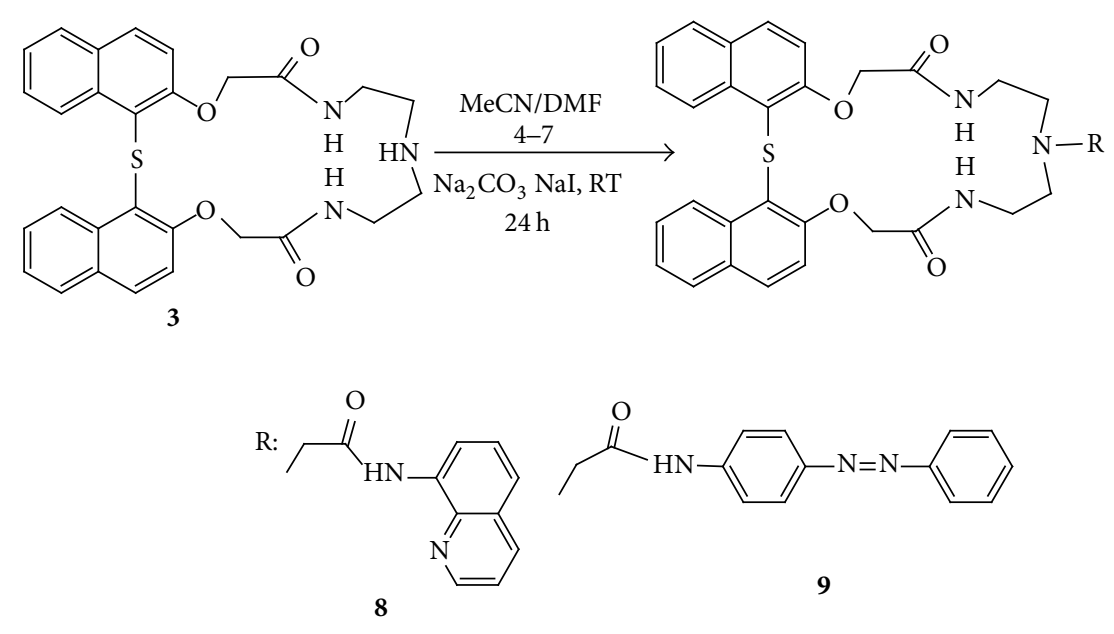

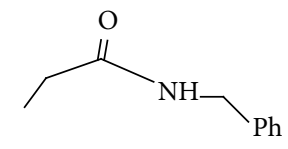

10

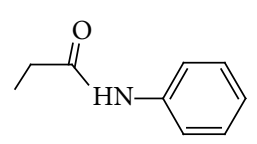

11

Scheme 3: Synthesis of lariats (8-11).<smiles>COC(=O)COc1ccc2ccccc2c1Sc1c(OCC(=O)OC)ccc2ccccc12</smiles>

2<smiles>Cc1ccc(S(=O)(=O)O)c(C)c1</smiles>

$\mathrm{TsOH}$<smiles>COC(=O)COc1ccc2ccccc2c1COc1ccc2ccccc2c1COC(=O)CO</smiles><smiles>CC(=O)COc1ccc2ccccc2c1Sc1c(OCC(=O)NCCNCCN)ccc2ccccc12</smiles>

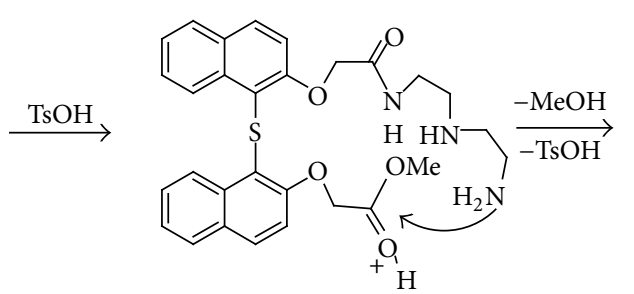<smiles>O=C(COc1c(OCC(=O)Nc2ccc3ccccc3c2)ccc2ccccc12)NCCNCCNCCO</smiles>

$\mathrm{TsO}^{-}$

FIGURE 2: Proposed mechanism for the formation of macrocycle (3). 
$2 \mathrm{H}$ ), 4.38-4.54 (two dubletes, $4 \mathrm{H}, J=12,18 \mathrm{~Hz}$ ), 7.13 (b, $1 \mathrm{H}), 7.32-7.48(\mathrm{~m}, 4 \mathrm{H}), 7.61(\mathrm{~b}, 2 \mathrm{H}), 7.88-7.92(\mathrm{dd}, J=3$, $6 \mathrm{~Hz}, 2 \mathrm{H}), 8.06-8.11(\mathrm{~b}, 2 \mathrm{H}), 8.40(\mathrm{~d}, 1 \mathrm{H}, J=9 \mathrm{~Hz}), 9.10$ (b, $1 \mathrm{H}), 10.90$ (b, 1H) ppm; ${ }^{13} \mathrm{C}$ NMR (75 MHz, DMSO$\left.\mathrm{d}_{6}\right) \delta: 169.53,155.73,134.06,129.98,129.37,128.94,128.62$, $127.30,124.15,124.07,119.48,114.52,67.25,55.66,53.95$, 34.17 ppm; MS (EI) m/z: $634\left[\mathrm{M}^{+}(11 \%), 514(12 \%), 434\right.$ (14\%), $376(13 \%), 318(11 \%), 300$ (21\%), 216 (26\%), 202 (24\%), 187 (42\%), 144 (81\%), 115 (100\%), 93 (24\%), 77 (12\%), 63 (28\%), 39 (27\%); Anal. Calcd. for $\mathrm{C}_{36} \mathrm{H}_{34} \mathrm{~N}_{4} \mathrm{O}_{5} \mathrm{~S}$ : C, 68.12; H, 5.40; N, 8.83. Found C, 68.10; H, 5.41; N, 8.84 .

\section{Results and Discussion}

The key step in this project is the synthesis of aza-macrocycle (3). Dinaphthol (1) was synthesized from the reaction of 2-naphthol and sulfur dichloride based on the reported procedure [40-42]. The corresponding diester (2) was synthesized according to the modified reported procedure from the reaction of $\mathbf{1}$ and methylchloroacetate in the presence of potassium carbonate and catalytic amounts of $\mathrm{KI}$ in $\mathrm{CH}_{3} \mathrm{CN}$ and DMF $(10: 1)$ solvent mixture at room temperature [43, 44]. Macrocycle (3) was synthesized from the reaction of diester (2) and diethylenetriamine in the presence of catalytic amounts of $\mathrm{p}$-toluene sulfonic acid $(\mathrm{p}$-TsOH) in methanol (Scheme 1) [43]. The proposed mechanism for the formation of macrocycle (3) is appeared in Figure 2.

Chloroamide derivatives (4-7) were synthesized from the reaction of corresponding amine and chloroacetyl chloride in the presence of triethylamine as base and in dichloromethane as solvent (Scheme 2) [40-42, 45], the lariat azacrowns (8-11) were synthesized from the reaction of chloroamides (4-7) and macrocycle (3). This reaction was carried out via a modified procedure in the presence of sodium carbonate and catalytic amounts of sodium iodide in $\mathrm{CH}_{3} \mathrm{CN} / \mathrm{DMF}(10: 1)$ at room temperature (Scheme 3) [46-48].

According to the previous works [33-38] on the applications of dinaphthyl sulfide receptors in host-guest chemistry, these new receptors are important candidates for a large number of studies such as complexation with metal ions, biological systems, and the applications in the preparation of nanostructures [44].

\section{Conclusions}

To summarize, we prepared a dinaphthyl sulfide aza crown, and then new dinaphthyl sulfide aza lariats (8-11) were prepared from the reaction of aza crown and some prepared chloroamides. This lariat is important receptors with naphthalene, quinolone, and azo groups. Based on the reported applications, the new receptors with pendant arms are strong complexation abilities and are potential candidates for hostguest chemistry and related areas.

\section{References}

[1] C. J. Pedersen, "Cyclic polyethers and their complexes with metal salts," Journal of the American Chemical Society, vol. 89, no. 26, pp. 7017-7036, 1967.

[2] C. J. Pedersen, "Crystalline salt complexes of macrocyclic polyethers," Journal of the American Chemical Society, vol. 92, no. 2, pp. 386-391, 1970.

[3] R. M. Izatt, K. Pawlak, J. S. Bradshaw, and R. L. Bruening, "Thermodynamic and kinetic data for macrocycle interaction with cations, anions, and neutral molecules," Chemical Reviews, vol. 95, no. 7, pp. 2529-2586, 1995.

[4] J. D. Chartres, L. F. Lindoy, and G. V. Meehan, "New heterotopic, linked macrocyclic systems derived from selectively protected macrocycles," Tetrahedron, vol. 62, no. 17, pp. 4173-4187, 2006.

[5] L. F. Lindoy, "New super- and supramolecular receptor systems-cages, chains, squares, and dendrimers incorporating macrocycles as structural elements," Journal of the Iranian Chemical Society, vol. 1, no. 1, pp. 1-9, 2004.

[6] M. Li, B. W. Chu, N. Zhu, and V. W. Yam, "Synthesis, structure, photophysics, electrochemistry, and ion-binding studies of ruthenium(II) 1,10-phenanthroline complexes containing thia, selena-, and aza-crown pendants," Inorganic Chemistry, vol. 46, no. 3, pp. 720-733, 2007.

[7] H. Mehta, H. Kaur, and S. Menon, "Molecular recognition of aromatic amines by coumarin substituted azacrown ether," Turkish Journal of Chemistry, vol. 34, no. 3, pp. 417-426, 2010.

[8] G. W. Gokel, Comprehensive Supramolecular Chemistry, vol. 1, Elsevier, Oxford, UK, 1996.

[9] T. J. Szczygelska and J. F. Biernat, "New chromogenic azothiacrown ethers-synthesis and properties," Polish Journal of Chemistry, vol. 76, no. 7, pp. 931-936, 2002.

[10] W. Zhang and J. S. Moore, "Shape-persistent macrocycles: structures and synthetic approaches from arylene and ethynylene building blocks," Angewandte Chemie, vol. 45, no. 27, pp. 4416-4439, 2006.

[11] M. Marjanovic, M. Kralj, F. Supek et al., "Antitumor potential of crown ethers: structure-activity relationships, cell cycle disturbances, and cell death studies of a series of ionophores," Journal of Medicinal Chemistry, vol. 50, no. 5, pp. 1007-1018, 2007.

[12] S. N. Dmitrieva, M. V. Churakova, A. I. Vedernikov, L. G. Kuz'mina, and S. P. Gromova, "New approach to the synthesis of dibenzodiazacrown ethers by ring transformation of dibenzocrown ether," Tetrahedron, vol. 67, no. 14, pp. 2530-2535, 2011.

[13] K. E. Krakowiak, J. S. Bradshaw, and D. J. Zamecka-Krakowiak, "Synthesis of aza-crown ethers," Chemical Reviews, vol. 89, no. 4, pp. 929-972, 1989.

[14] C. Tu, K. Surowiec, J. Gega, D. W. Purkiss, and R. A. Bartsch, "Di-ionizable calix[4]arene-1,2-crown-5 and -crown-6 ethers in cone conformations: synthesis and divalent metal ion extraction," Tetrahedron, vol. 64, no. 7, pp. 1187-1196, 2008.

[15] H. O. Davies, J. R. Dilworth, D. V. Griffiths, J. R. Miller, and Y. Zheng, "The synthesis and crystal structures of the amide NS3 macrocycle L1, and the silver complexes $[\mathrm{Ag}(\mathrm{L} 1)] \mathrm{n}[\mathrm{CF} 3 \mathrm{SO} 3] \mathrm{n}$ and of $[\mathrm{Ag}(\mathrm{L} 2)] 2[\mathrm{CF} 3 \mathrm{SO} 3] 2$ (where $\mathrm{L} 1=9$-oxo-1,4,7-trithia-10-azacyclododecane and L2=7-oxo2,5,11-trithia-8-azatetradecane-12-orthobenzenophane)," Polyhedron, vol. 18, no. 3-4, pp. 459-467, 1998. 
[16] G. W. Gokel, "Lariat ethers: from simple sidearms to supramolecular systems," Chemical Society Reviews, vol. 21, pp. 39-47, 1992.

[17] Y. Li, U. C. Yoon, and M. H. Hyun, "Phosphorescent azacrown ether-appended iridium (III) complex for the selective detection of $\mathrm{Hg}^{2+}$ in aqueous acetonitrile," Bulletin of the Korean Chemical Society, vol. 32, no. 1, pp. 122-126, 2011.

[18] G. W. Gokel, L. J. Barbour, R. Ferdani, and J. Hu, "Lariat ether receptor systems show experimental evidence for alkali metal cation $-\pi$ interactions," Accounts of Chemical Research, vol. 35, no. 10, pp. 878-886, 2002.

[19] Y. Habata, S. Akabori, J. S. Bradshaw, and R. M. Izatt, "Synthesis of armed and double-armed macrocyclic ligands by the mannich reaction: a short review," Industrial and Engineering Chemistry Research, vol. 39, no. 10, pp. 3465-3470, 2000.

[20] S. Watanabe, M. Tsesarskaja, B. C. Lynn et al., "Macrocycles used as models to probe the interaction of a fatty acid derivative with its natural receptor," Pure and Applied Chemistry, vol. 65, no. 3, pp. 467-472, 1993.

[21] T. B. Lj and P. R. Danesi, "Complexation of some substituted macrocyclic polyethers with alkali metal cations in methanol, dimethylsulfoxide and acetonitrile," Journal of Inorganic and Nuclear Chemistry, vol. 41, no. 6, pp. 833-837, 1979.

[22] M. Robnik-Šikonja and I. Kononenko, "Theoretical and empirical analysis of ReliefF and RReliefF," Machine Learning, vol. 53, no. 1-2, pp. 23-69, 2003.

[23] R. A. Bartsch, S. N. Ivy, J. Lu et al., "Metal ion extraction by lariat ethers with 'tunable' proton-ionizable groups," Pure and Applied Chemistry, vol. 70, no. 12, pp. 2393-2400, 1998.

[24] L. D. Bratton, B. Strzelbicka, and R. A. Bartsch, "Synthesis of Npivot lariat ethers and their metal ion complexationbehavior," Arkivoc, vol. 2003, no. 12, pp. 80-88, 2003.

[25] L. Pu, "1,1'-binaphthyl dimers, oligomers, and polymers: molecular recognition, asymmetric catalysis, and new materials," Chemical Reviews, vol. 98, no. 7, pp. 2405-2494, 1998.

[26] P. Kocovsky, S. Vyskocil, and M. Smrchina, "Nonsymmetrically substituted $1,1^{\prime}$-binaphthyls in enantioselective catalysis," Chemical Reviews, vol. 103, no. 8, pp. 3213-3246, 2003.

[27] Y. Chen, S. Yekta, and A. K. Yudin, "Modified BINOL ligands in asymmetric catalysis," Chemical Reviews, vol. 103, no. 8, pp. 3155-3211, 2003.

[28] D. Cornelis, E. Franz, I. Asselberghs, K. Clays, T. Verbiest, and G. Koeckelberghs, "Interchromophoric interactions in chiral $\mathrm{X}$-type $\pi$-conjugated oligomers: a linear and nonlinear optical study," Journal of the American Chemical Society, vol. 133, no. 5, pp. 1317-1327, 2011.

[29] C. Coluccini, A. Castelluccio, and D. Pasini, "Chemoselective functionalization of 3,3/-substituted BINOL derivatives," Journal of Organic Chemistry, vol. 73, no. 11, pp. 4237-4240, 2008.

[30] M. Caricato, C. Coluccini, D. Dondi, D. A. Vander Griend, and D. Pasini, "Nesting complexation of $\mathrm{C}_{60}$ with large, rigid $\mathrm{D}_{2}$ symmetrical macrocycles," Organic and Biomolecular Chemistry, vol. 8, no. 14, pp. 3272-3280, 2010.

[31] C. Coluccini, D. Dondi, M. Caricato, A. Taglietti, M. Boiocchi, and D. Pasini, "Structurally-variable, rigid and opticallyactive $D_{2}$ and $D_{3}$ macrocycles possessing recognition properties towards $\mathrm{C}_{60}$," Organic and Biomolecular Chemistry, vol. 8, no. 7, pp. 1640-1649, 2010.
[32] M. Caricato, N. J. Leza, C. Gargiulli, G. Gattuso, D. Dondi, and D. Pasini, "Synthesis and anion recognition properties of shapepersistent binaphthyl-containing chiral macrocyclic amides," Beilstein Journal of Organic Chemistry, vol. 8, pp. 967-976, 2012.

[33] A. Shockravi, M. Shamsipur, H. Fattahi et al., "Efficient synthesis and metal cations complexation of some novel dinaphthosulfide-substituted macrocyclic diamides," Journal of Inclusion Phenomena and Macrocyclic Chemistry, vol. 61, no. 12, pp. 153-160, 2008.

[34] A. Shockravi, M. Chaloosi, E. Rostami et al., "Modified BINOL podands: synthesis of dinaphthosulfide podands and their application in spectrophotometric determination of toxic metals," Phosphorus, Sulfur and Silicon and the Related Elements, vol. 182, no. 9, pp. 2115-2123, 2007.

[35] M. Taghdiri, R. Behjatmanesh-Ardakani, A. Shockravi, F. Taheri, and H. J. Fattahi, "Study on the interaction between dinaphthosulfide-substituted macrocyclic diamides and some metal ions: experimental measurements vs. quantum mechanical calculations," Journal of Molecular Modeling, vol. 73, no. 1-4, pp. 255-262, 2012.

[36] M. H. Mashhadizadeh, H. Khani, A. Shockravi, and M. Sadeghpour, "Determination of ultratrace levels of lead (II) in water samples using a modified carbon paste electrode based on a new podand," Materials Science and Engineering C, vol. 31, no. 8, pp. 1674-1680, 2011.

[37] M. H. Mashhadizadeh, A. Shockravi, Z. Khoubi, and D. Heidarian, "Efficient synthesis of a new podand and application as a suitable carrier for silver ion-selective electrode," Electroanalysis, vol. 21, no. 9, pp. 1041-1047, 2009.

[38] M. H. Mashhadizadeh, H. Khani, and A. Shockravi, "Used a new aza-thia-macrocycle as a suitable carrier in potentiometric sensor of copper (II)," Journal of Inclusion Phenomena and Macrocyclic Chemistry, vol. 68, no. 1-2, pp. 219-227, 2010.

[39] M. M. A. Boojar and A. Shockravi, "On the cytotoxicity and status of oxidative stress of two novel synthesized tri-aza macrocyclic diamides as studied in the V79 cell lines," Bioorganic and Medicinal Chemistry, vol. 15, no. 10, pp. 3437-3444, 2007.

[40] W. S. Gump and J. C. Vitucci, "2-Hydroxyphenyl sulfoxides and 2-hydroxyphenyl sulfones," Journal of the American Chemical Society, vol. 67, no. 2, pp. 238-240, 1945.

[41] M. Gazdar and S. Smiles, "CCXXXVI.-aromatic hydroxysulphoxides," Journal of the Chemical Society, Transactions, vol. 97, pp. 2248-2253, 1910.

[42] N. Kon, N. Iki, Y. Yamane, S. Shirasaki, and S. Miyano, "Facile synthesis of thiacalix [n] arenes $(\mathrm{n}=4,6$, and 8) consisting of $\mathrm{p}$ tert-butylphenol and methylene/sulfide alternating linkage and metal-binding property of the $\mathrm{n}=4$ homologue," Tetrahedron Letters, vol. 45, pp. 207-211, 2004.

[43] E. Rostami, A. Shockravi, H. Fattahi et al., "BINOL aza macrocycle derivatives: synthesis of dinaphthosulfone aza macrocycles using p-toluenesulfonic acid ( $\mathrm{p}-\mathrm{TsOH})$ in methanol as an efficient route and evaluation of their 1H NMR spectra," Phosphorus, Sulfur and Silicon and the Related Elements, vol. 184, no. 8, pp. 2066-2077, 2009.

[44] T. V. Sangeetha and M. Fredimoses, "Inhibition of mild copper metal corrosion in $\mathrm{HNO}_{3}$ medium by acid extract of Azadirachta Indica seed," E-Journal of Chemistry, vol. 8, pp. S1-S6, 2011.

[45] J. Y. Lee, S. K. Kim, J. H. Jung, and J. S. Kim, "Bifunctional fluorescent calix[4] arene chemosensor for both a cation and an anion," The Journal of Organic Chemistry, vol. 70, no. 4, pp. 1463-1466, 2005. 
[46] R. S. Dhillon, S. E. Madbak, F. G. Ciccone, M. A. Buntine, S. F. Lincoln, and K. P. Wainwright, "Diastereomeric 1,4,7,10tetrakis((S)-2-hydroxypropyl)1,4,7,10-tetraazacyclododecane and its alkali metal complex ions. A nuclear magnetic resonance, potentiometric titration, and molecular orbital study," Journal of the American Chemical Society, vol. 119, no. 26, pp. 6126-6134, 1997.

[47] S. L. Whitbread, P. Valente, M. A. Buntine, P. Clements, S. F. Lincoln, and K. P. Wainwright, "Diastereomeric $\Delta$ 1,4,7,10-tetrakis((R)-2-hydroxy-2-phenylethyl)1,4,7,10-

tetraazacyclododecane and its alkali-metal complex ions. A potentiometric titration, nuclear magnetic resonance, and molecular orbital study," Journal of the American Chemical Society, vol. 120, no. 12, pp. 2862-2869, 1998.

[48] P. A. Pittet, D. Früh, V. Tissières, and J. C. G. Bünzli, "Isomerization kinetics of lanthanide(III) complexes with the pendant-arm macrocyclic ligand 1,4,7,10-tetrakis(2hydroxyethyl)-1,4,7,10-tetraazacyclododecane," Journal of the Chemical Society, Dalton Transactions, no. 5, pp. 895-900, 1997. 

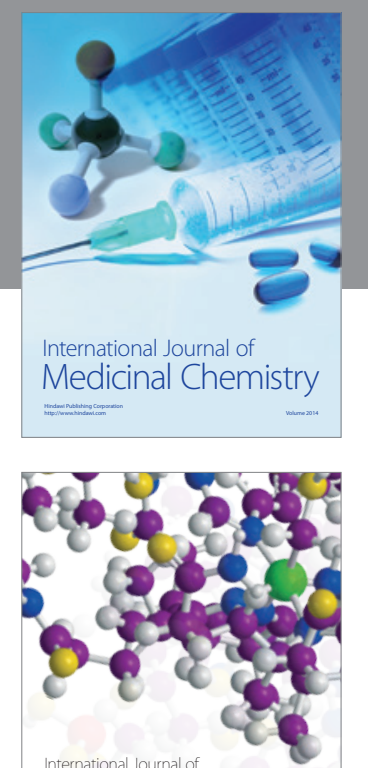

\section{Carbohydrate} Chemistry

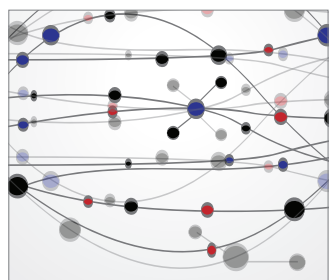

The Scientific World Journal
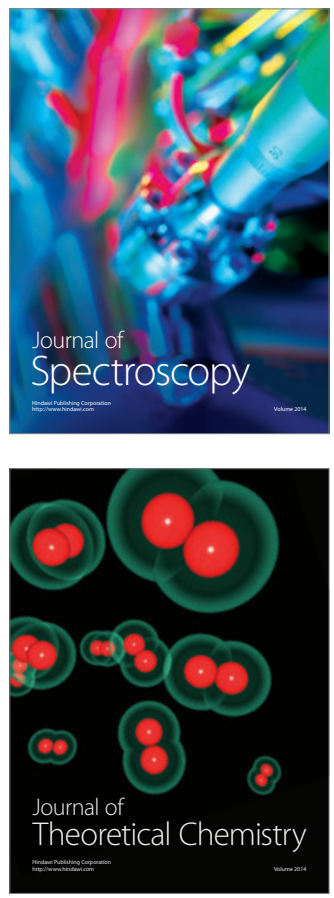
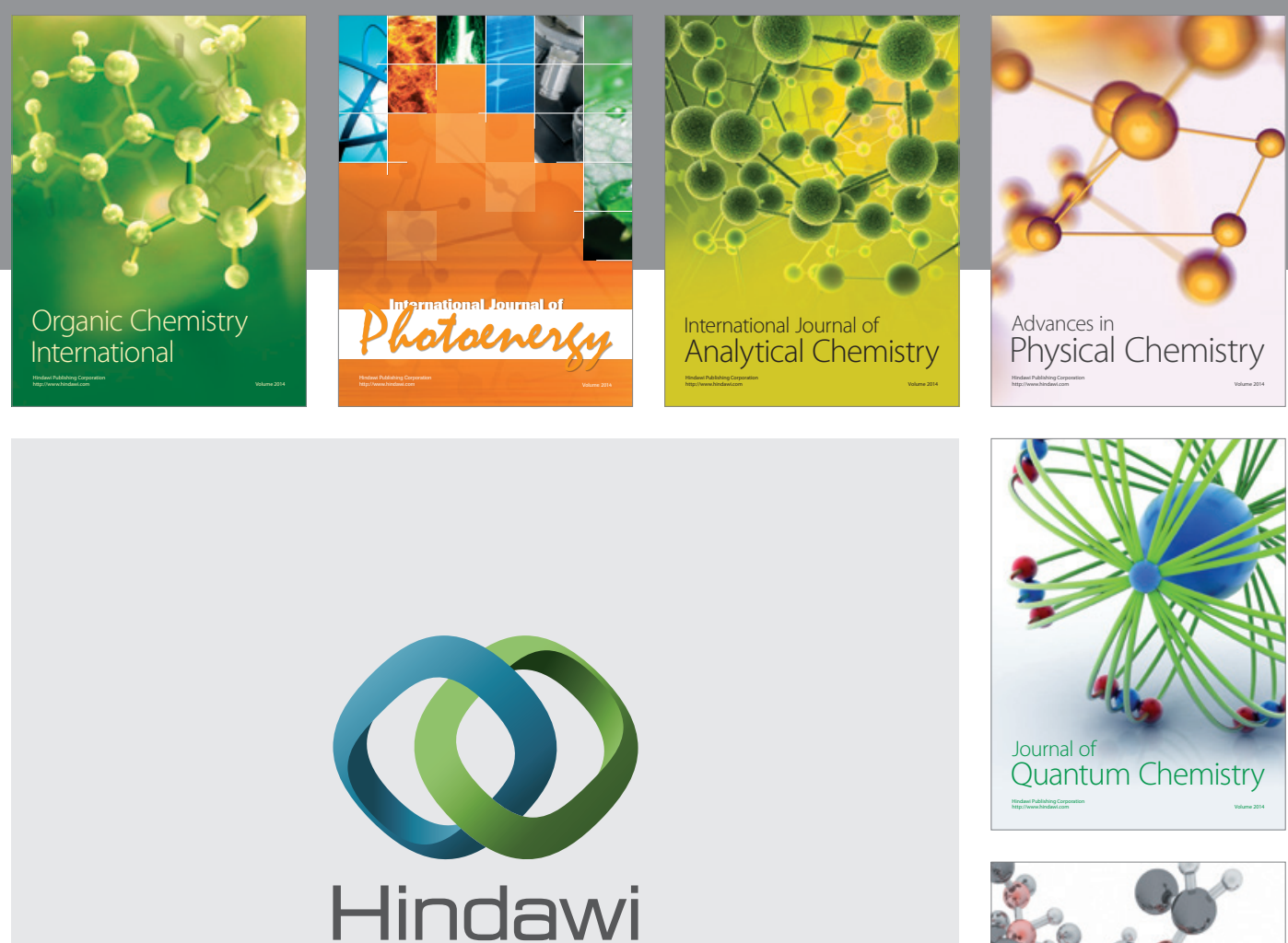

Submit your manuscripts at

http://www.hindawi.com

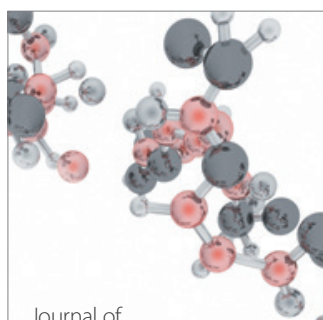

Analytical Methods

in Chemistry

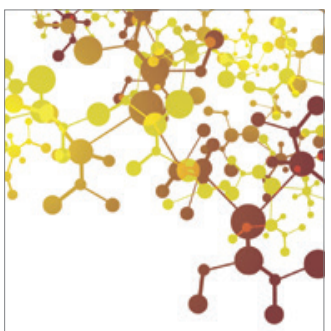

Journal of

Applied Chemistry

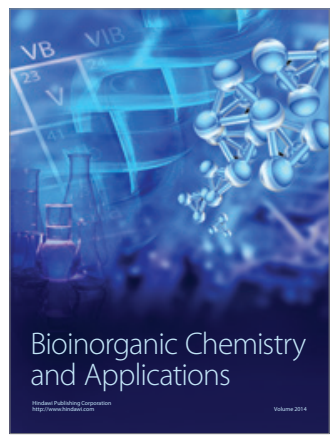

Inorganic Chemistry
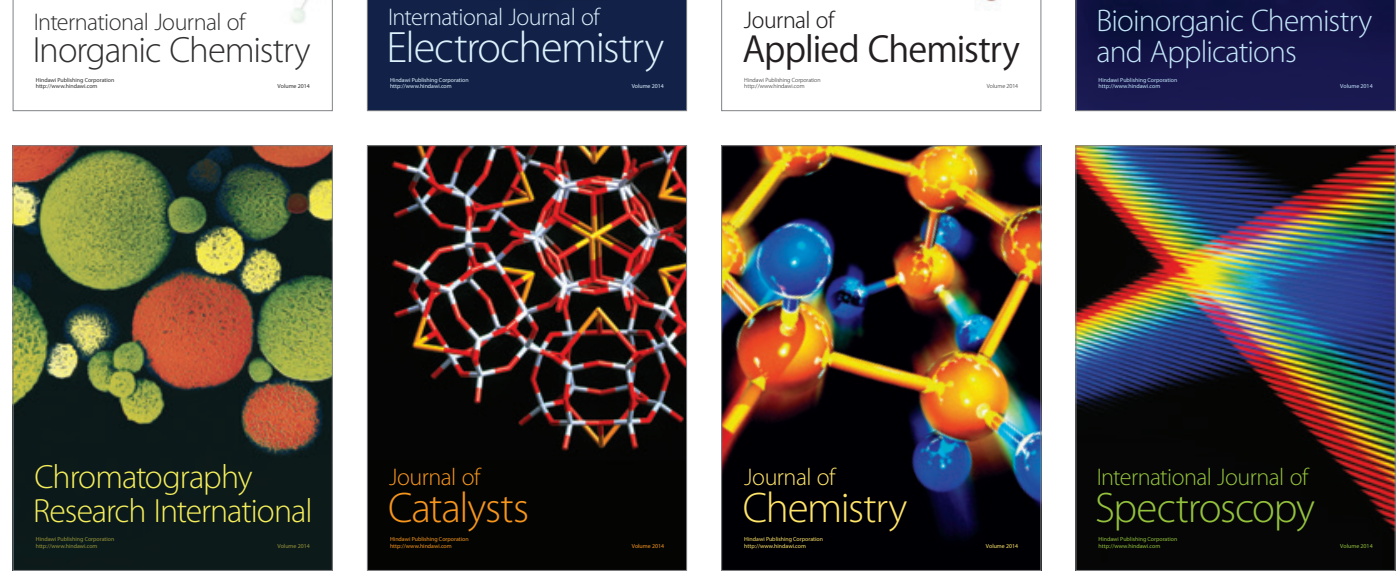